\title{
ASSESSMENT OF THE CONSTRUCTIONALITY OF THE STRUCTURE IN THE ASSEMBLY PROCESSES
}

\author{
Józef Matuszek ${ }^{1}$, Tomasz Seneta ${ }^{1}$, Luboslav Dulina ${ }^{1}$, Eleonóra Bigošová²,*
}

${ }^{1}$ Department of Production Engineering, Faculty of Mechanical Engineering and Computer Science, University of Technology and Humanities in Bielsko-Biala, Poland

${ }^{2}$ Department of Industrial Engineering, Faculty of Mechanical Engineering, University of Zilina, Zilina, Slovakia

*E-mail of corresponding author: eleonora.bigosova@fstroj.uniza.sk

\section{Resume}

The paper presents the methodology of designing the production process of a new product from the point of view of the criterion of the assembly operations technology (Design for Assembly - DFA) in the automotive industry. The article describes methods and techniques used during the implementation of a new product into production. The impact of the methods on improving the assembly technology of a complex product is described. Suggestions for improving for unit and small series production are presented.

Available online: https://doi.org/10.26552/com.C.2021.3.B200-B210

\section{Article info}

Received 12 November 2020

Accepted 29 November 2020

Online 14 April 2021

\section{Keywords:}

production process design, construction manufacturability, unit, small-lot production

ISSN 1335-4205 (print version) ISSN 2585-7878 (online version)

\section{Introduction}

To evaluate the technology of the assembly and defined guidelines for shaping the design process due to PDM (Product Data Management - PDM), different methods may be used. In the automotive industry, widely recognised methods known as DFA were proposed and described for the first time by G. Boothroyd and P. Dewhurst in 1983. The DFA methods are constantly being refined due to technical progress. They allow a more efficient evaluation of the possibility of reducing the number of product components and estimating the costs of machining processes and assembly of the analysed product. By introducing the DFA methods into the design process, the new product design team can propose improved design solutions, which are characterized by better indicators, simpler construction and components, which directly affect the simplification of assembly operations.

The most popular methods of the DFA practice are Lucas DFA, Boothroyd and Dewhurst (B \& D), Hitachi AEM. [1-3].

Development of machining technology (thanks to the automation and extension of the possibility of making objects of complex construction), in connection with a significant share of manual work in the assembly processes of finished products, has led to a change in the approach to the production of new products. There has been a development of methods of determining the production costs. The share of assembly costs in the production costs of products has greatly increased [4-6]. The design process of the new product is shown in Figure 1.

The design process should be determined from the point of view of different usability criteria. The assessment is based on marketing and conceptual preparation; documentation - construction, production and organization; implementation of the production process; distribution; conditions for the operation and decommissioning of the product.

\section{Proposal to modify the methods to assess the manufacturability design}

\subsection{Input assumptions}

As a part of the work, based on analysing and comparing existing methods and algorithms to improve the product's technological efficiency, it was proposed to improve the abovementioned assessment methods.

The presented methods are focused on activities that reduce assembly times, which ultimately reduces the costs of assembly operations. An additional factor that reduces assembly times is the unification and standardization of product components, which can be 


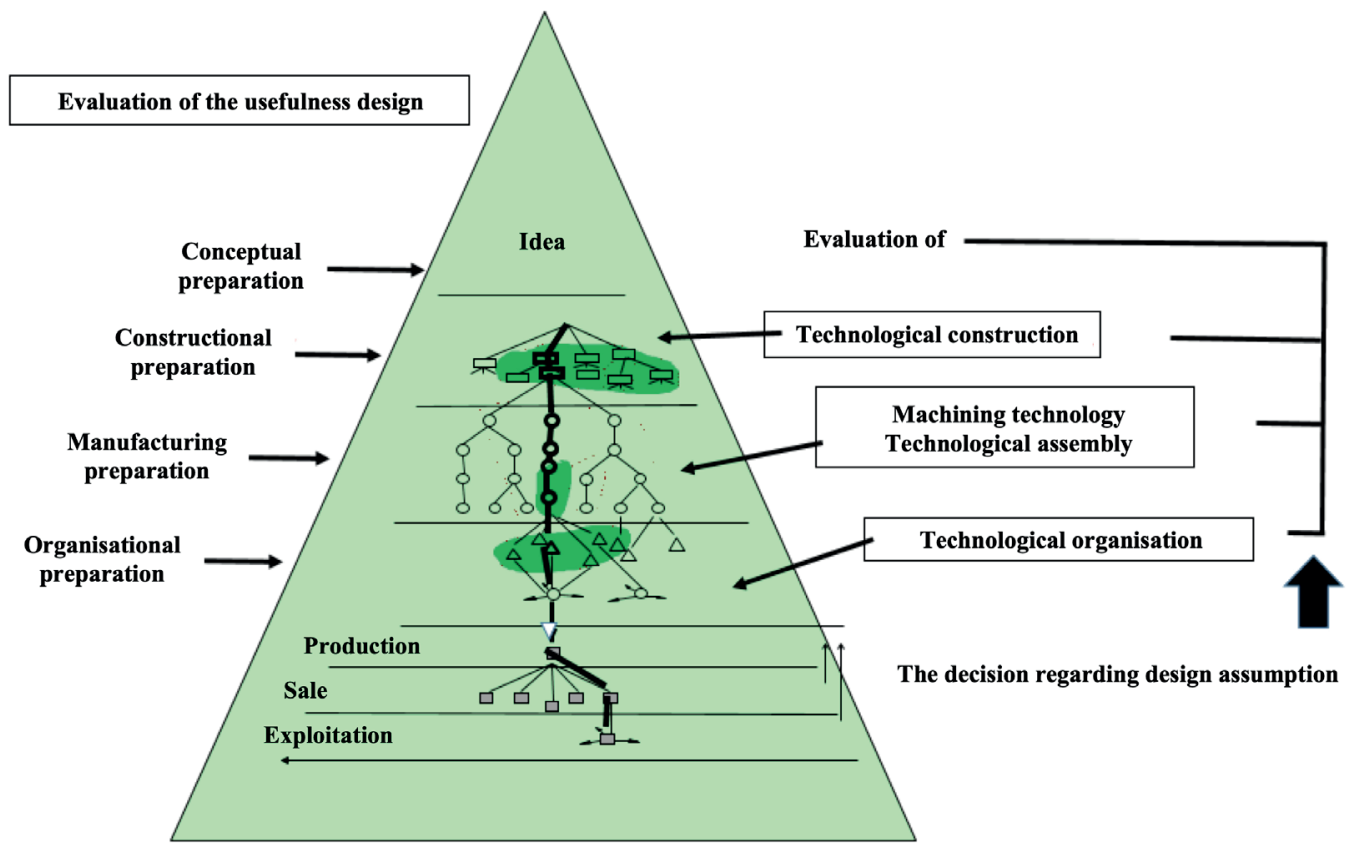

Figure 1 The course of designing the production process of a new product [6]

determined by an index of component unification. The unification of the product components allows, in turn, to rationalize production processes in the form of group processing applications. The proposed improvement of the above methods meets the development trends in the automotive industry consisting of continuous linear improvement of product design, use of components included in the assembly in many versions and brands of final products [7-8].

The presented methods of assessing manufacturability of the structure may also be used in the production of other products. As an example can be presented analysis of the structure's efficiency on the single-stage gear transmission used to drive devices installed on means of transport example (Figure 1) [9-11].

\subsection{Modified Boothroyd Dewhurst DFA and Lucas DFA methods}

The final stage in the Boothroyd \& Dewhurst DFA method is calculation for which it is necessary to know the sum of the number of operations, the total time of the operation, the total costs of the operation, the theoretical minimum number of parts and the DFMA ${ }_{\text {index }}[12-13]$.

In the Lucas DFA method, it is necessary to know the project performance indicator $\left(W_{e p}=D F M A_{\text {index }}\right)$, manoeuvrability $\left(W_{\operatorname{man}}\right)$ and assemblability $\left(W_{m o n}\right)$. Determination of the abovementioned quantities to determine the effects of rationalization takes place before and after the assessment of technology [14].

Similarly, for a more detailed analysis, the authors propose to define the technological indicators for both above-mentioned methods, with a view to harmonising the components of the product and the possibility of using the group processing and increasing serial production. The structure efficiency index after analysis for unified and standardised components is:

$W t k_{U N K}=\left(C_{U N K} / C_{t}\right) \cdot 100 \%$

where: $W t k_{U N K}$ - the structure efficiency index for unified and standardised components

$C_{U N K}$ - the sum of unified and standardized assembly components,

$C_{t}$ - total components.

The structure efficiency index after the analysis of component structure, enabling group processing is:

$W t k_{O G}=\left(C_{O G} / C_{t}\right) \cdot 100 \%$

where: $W t k_{O G}$ - the structure efficiency index of component structure enabling group processing

$C_{O G}$ - the sum of the components that can potentially be implemented using the group processing technologies in manufacturing processes,

$C_{t}$ - total components.

\section{Examples}

\subsection{The Boothroyd and Dewhurst DFA method}

According to the Boothroyd \& Dewhurst DFA method for the gear prototype design (Figure 1), the assembly process was defined, the fragment of which is presented in Tables 1-3. The DFMA indicator before making the change is [15]:

$\mathrm{DFMA}_{\text {index }}=\left(t_{a} \cdot L_{o}\right) / T_{o}$, 
for many parts, it can be assumed that: $L_{o}=A$ and where:

DFMAindex - the project performance indicator,

$A$ - number of parts necessary for functioning of the product (it was assumed in the study that $L_{o}=A=C_{t}$ ), $t_{a}$ - assembly time of the basic ideal part (based on Boothoroyd; $\mathrm{t}_{\mathrm{a}}=3 \mathrm{~s}$ ),

$T_{o}$ - total assembly time of the product).

$$
D F M A_{\text {index }}=\left(3 \cdot L_{o}\right) / T_{o},
$$

(4) $I_{m o n}$ - assembly index for a given part of the product, where: $L_{o}$ - the total number of operations to assembly $\left(L_{0}=A\right)$,
$T_{\text {man }}$ - time manipulation index for the given product,

For each assembled part and for each defined step of the assembly process, the following values were determined:

$L_{o}=\Sigma l_{o i}, T_{o}=I_{\text {man }}+I_{m o n}=\Sigma T_{\text {man }}+\Sigma T_{\text {mon }}$,

where: $l_{o i}$ - i-th assembly operation,

$I_{\text {man }}$ - manipulation index for a given part of the product

$T_{\text {mon }}$ - assembly time for a given component of the product.
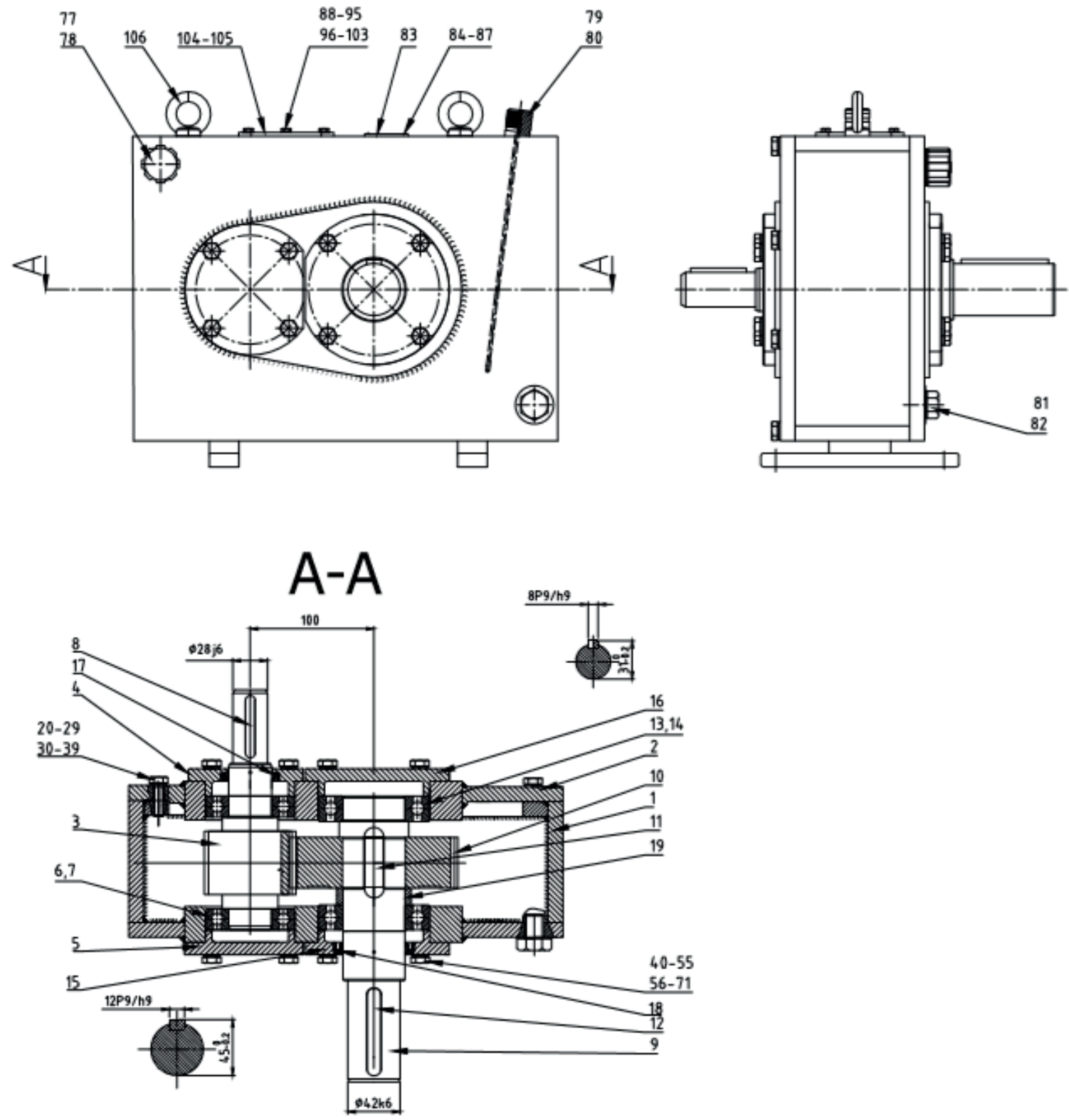

Figure 2 Diagram of the gear unit being analysed

1 - body, 2 - cover, 3 - pinion, 4 - pinion cover I, 5 - pinion cover II, 6- 7 - bearings pinion, 8 - pinion key, 9 - shaft, 10 - gear, 11 - gear key, 12 - shaft key, 13-14 - bearings shaft, 15 - shaft cover I, 16 - shaft cover II, 17 - pinion seal, 18 - shaft seal, 19 - spacer rings, 20-29 - body bolts, 30-39 - bolt washers to the body, 40-55 - cover bolts, 56-71 - bolt washers for covers, 72-76 - Monolith gasket, 77-78 - vent with cover gasket, 79-80 - oil gauge with gasket, 81 - oil plug, 82 - oil plug gasket, 83 - nameplate, 84-87 - rivet pin, 88-95 - sight glass screws, 96-103 - washers for sight glass screws , 104 - sight glass gasket, 105 - sight glass 

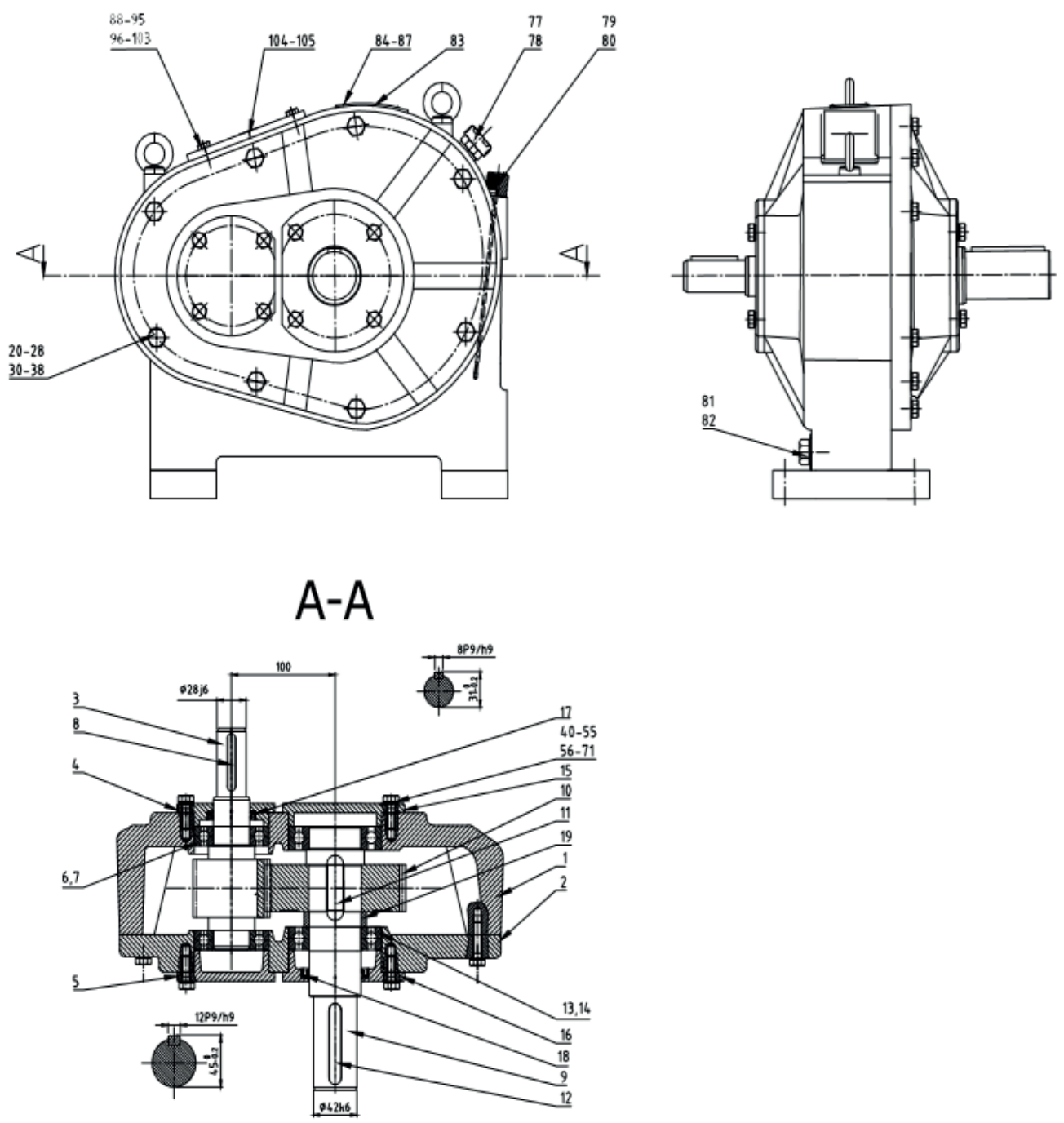

Figure 3 Diagram of the gear unit analysed

1 - body, 2 - cover, 3 - pinion, 4 - pinion cover I, 5 - pinion cover II, 6- 7 - bearings pinion, 8 - pinion key, 9 - shaft, 10 - gear, 11 - gear key, 12 - shaft key, 13-14 - bearings shaft, 15 - shaft cover I, 16 - shaft cover II, 17 - pinion seal, 18 - shaft seal, 19 - spacer rings, 20-29 - body bolts, 30-39 - bolt washers to the body, 40-55 - cover bolts, 56-71 - bolt washers for covers, 72-76 - Monolith gasket, 77-78 - vent with cover gasket, 79-80 - oil gauge with gasket, 81 - oil plug, 82 - oil plug gasket, 83 - nameplate, 84-87 - rivet pin, 88-95 - sight glass screws, 96-103 - washers for sight glass screws , 104 - sight glass gasket, 105 - sight glass

To improve the gear assembly technology, design of the proposed gear was changed (Figure 2). The change was adapted to the production conditions depending on the serial production. Limiting the scope of changes resulting from the serial production is forced by the costs of machining and assembly itself, which, with significant changes improving the technology of the structure, requires costly tooling (workshop aids) related to machining and assembly. Such changes are profitable in the conditions of mass production [16-18].

The gearbox dimensions result (Figure 2) from the ratio $i=1.95$, the number of pinion teeth $z_{1}=22$; the gear wheel $z_{2}=43$; the module $m_{n}=3.00 \mathrm{~mm}$, the tooth angle inclination $\beta=10^{\circ}$, the width of the teeth $\mathrm{b}=15 \mathrm{~m}_{\mathrm{n}}$.

For the mass production, the material and form of the body were changed, from the welded structure to the cast structure with the division perpendicular to the axis of the shafts. This way, two bearing caps were eliminated, the remaining caps would be pressed in, thus eliminating washers and screws; the assembly of individual components was replaced for the assembly of assemblies that will only be mounted vertically using tooling. In unit and small-lot production similarly, it was proposed to change the body to a cast form, but the division of the body parallel to the shaft axis was kept. At the same time, the same construction form was used to assemble gears of different sizes (different transmitted powers) and different ratios, materials and forms of pinion and gear wheels were unified, ensuring constant unified inter-axle distances and unified different ratios at individual gear stages (from the same elements gears are also mounted in multi-stage gears); the diameters of bearing openings have been unified, - pinion units with mounted bearings, shaft with mounted gear wheel and bearings mounted on the shaft are mounted to the gear 
Table 1 Results of the technology analysis by the Boothroyd \& Dewhurst method of the gearbox

\begin{tabular}{|c|c|c|c|c|c|c|c|}
\hline \multicolumn{4}{|c|}{ details of assembly and components } & \multicolumn{4}{|c|}{ product data } \\
\hline no. & description & $\begin{array}{l}\text { initial assumption of the } \\
\text { process }\end{array}$ & $\begin{array}{l}\text { repetitions } \\
\text { of } \\
\text { activities }\end{array}$ & $\begin{array}{l}\text { thickness } \\
\text { (t mm) }\end{array}$ & $\begin{array}{c}\text { size } \\
(\mathrm{s} \mathrm{mm})\end{array}$ & $\begin{array}{l}\text { rotation } \\
\text { alpha }\left({ }^{\circ}\right)\end{array}$ & $\begin{array}{l}\text { rotation } \\
\text { beta }\left(^{\circ}\right)\end{array}$ \\
\hline 1 & main housing no.1 & pick up & 1 & 120 & 309 & 360 & 360 \\
\hline 2 & bearing no. 6 & press to main housing no.1 & 1 & 17 & 72 & 180 & 0 \\
\hline 3 & bearing no.13 & press to main housing no.1 & 1 & 20 & 90 & 180 & 0 \\
\hline 4 & main shaft no. 3 & press to bearing no. 6 & 1 & 37 & 194 & 360 & 0 \\
\hline 5 & slow-speed shaft no.9 & pick up & 1 & 28 & 216 & 360 & 360 \\
\hline 8 & spacer no. 19 & assembly on shaft subassy & 1 & 4 & 60 & 180 & 0 \\
\hline 9 & preheat gear no.9 & preheat gear no. 9 to $180 \mathrm{deg}$. & 1 & & & & \\
\hline 10 & shaft subassy & press to bearing no.14 & 1 & 136 & 216 & 360 & 360 \\
\hline 11 & cover no. 2 & pick up & 1 & 25 & 288 & 360 & 360 \\
\hline 12 & bearing no.7 & press to cover no. 16 & 1 & 17 & 72 & 180 & 0 \\
\hline 13 & bearing no.14 & press to cover no. 15 & 1 & 20 & 90 & 180 & 0 \\
\hline 18 & spring washer z8.2 & assem with screw & 10 & 4 & 14 & 180 & 0 \\
\hline 19 & screw with washer & $\begin{array}{c}\text { tighten cover no. } 2 \text { to main } \\
\text { housing }\end{array}$ & 10 & 4 & 20 & 360 & 0 \\
\hline 20 & cover no. 5 & pick up & 1 & 16 & 100 & 360 & 360 \\
\hline 21 & screw m8x20 & pick up & 4 & 4 & 20 & 360 & 0 \\
\hline 22 & spring washer z8.2 & assem with screw & 4 & 4 & 14 & 180 & 0 \\
\hline 23 & monolith seal & sealing & 1 & & & & \\
\hline \multirow[t]{2}{*}{24} & screw with washer & $\begin{array}{l}\text { tighten cover } 5 \text { to main housing } \\
\text { no.1 }\end{array}$ & 4 & 4 & 14 & 180 & 0 \\
\hline & \multicolumn{2}{|c|}{$\begin{array}{l}\text { total number of parts/operations } \\
\text { before changes }\end{array}$} & 113 & & & & \\
\hline & $\begin{array}{l}\text { serial and mass pro } \\
\text { oretically } 13 \text { ), includi }\end{array}$ & $\begin{array}{l}\text { ction. after the change - } 32 \text { (the } \\
\text { workpieces - } 9 \text {, in group machi }\end{array}$ & tically 22 & luding & $\begin{array}{l}\text { ed eler } \\
\text { and } 7 \mathrm{r}\end{array}$ & $\begin{array}{l}\text { s - } 23 \\
\text { ctively) }\end{array}$ & \\
\hline
\end{tabular}

body, washers, screws fastening covers to the body were unified, the whole series was unified gears, sight glasses and their fastening elements, workshop aids have been unified related to gear machining and assembly (e.g. bearing assembly, for sealing contact surfaces) [19-20].

Results of the technological analysis (for changes made for the mass production) are presented in Tables 1-3. In addition, the table provides data on transmission parts after a performance analysis for the conditions of the unit and small-lot production [21].

Based on the data set out in Tables 1-3, the following indicators of the gear structure design were obtained (the analyses assumed that $L_{o}=A=C_{e}$ ):

Indicator before the gear structure changes is (Figure 2):

$D F M A_{w p z}=\left(3 \cdot A / T_{i p z}\right) \cdot 100 \%=$

$=(3 \cdot 105 / 683 \cdot 19) \cdot 100 \%=46 \%$.

(6) $S_{t p z}$ - number of A-type transmission components before

Indicator after the changes for Unit and small-lot production:

$D F M A_{w p o}=\left(3 \cdot A / T_{i p z}\right) \cdot 100 \%=$

$=(3 \cdot 85 / 683.19) \cdot 100 \%=37 \%$. changes,

After the changes for serial and mass production (Figure 3):

$D F M A_{w p o}=\left(3 \cdot A / T_{i p z}\right) \cdot 100 \%=$

$=(3 \cdot 32 / 683 \cdot 19) \cdot 100 \%=14 \%$.

Theoretical indicator (for the theoretical number of parts - 22, after inserting the push-fit connections and eliminating subsequent fasteners):

$D F M A_{\text {wpo }}=\left(3 \cdot / T_{i p o}\right) \cdot 100 \%=$

$=(3 \cdot 22 / 683.19) \cdot 100 \%=10 \%$,

where:

$D F M A_{w p z}$ - indicator before the gear structure changes, $D F M A_{w p o}$ - indicator after changes made to the gear design,

$S_{t p z}$ - number of A-type transmission components before the changes,

$T_{i p z}$ - gearbox assembly time before structural changes,

$T_{i p o}$-gearbox assembly time after the structural changes. According to calculations, it can be stated that the 
Table 2 Results of the technology analysis by the Boothroyd \& Dewhurst method of the gearbox-Continue

\begin{tabular}{|c|c|c|c|c|c|c|c|c|}
\hline \multicolumn{4}{|c|}{ details of assembly and components } & \multicolumn{2}{|c|}{ manoeuvrability } & \multicolumn{2}{|c|}{ assemblability } & \multirow{2}{*}{$\begin{array}{l}\text { operation } \\
\text { time index }\end{array}$} \\
\hline no. & description & $\begin{array}{l}\text { initial assumption of } \\
\text { the process }\end{array}$ & $\begin{array}{l}\text { repetitions of } \\
\text { activities }\end{array}$ & code & $\begin{array}{l}\text { time } \\
\text { index }\end{array}$ & code & time index & \\
\hline 1 & main housing no.1 & pick up & 1 & 30 & 1.95 & 00 & 1.5 & 3.45 \\
\hline 2 & bearing no. 6 & $\begin{array}{l}\text { press to main housing } \\
\text { no.1 }\end{array}$ & 1 & 00 & 1.13 & 31 & 5.0 & 6.13 \\
\hline 3 & bearing no.13 & $\begin{array}{l}\text { press to main housing } \\
\text { no.1 }\end{array}$ & 1 & 00 & 1.13 & 31 & 5.0 & 6.13 \\
\hline 4 & main shaft no.3 & press to bearing no. 6 & 1 & 88 & 6.35 & 41 & 7.5 & 13.85 \\
\hline 5 & slow-speed shaft no.9 & pick up & 1 & 30 & 1.95 & & & 1.95 \\
\hline 8 & spacer no. 19 & $\begin{array}{l}\text { assembly on shaft } \\
\text { subassy }\end{array}$ & 1 & 00 & 1.13 & 01 & 2.5 & 3.63 \\
\hline 9 & preheat gear no.9 & $\begin{array}{c}\text { preheat gear no. } 9 \text { to } \\
180 \mathrm{deg} .\end{array}$ & 1 & & & 99 & 12.0 & 12.00 \\
\hline 10 & shaft subassy & press to bearing no.14 & 1 & 30 & 1.95 & 51 & 9.0 & 10.95 \\
\hline 11 & cover no. 2 & pick up & 1 & 30 & 1.95 & & & 1.95 \\
\hline 12 & bearing no.7 & press to cover no. 16 & 1 & 00 & 1.13 & 31 & 5.0 & 6.13 \\
\hline 13 & bearing no.14 & press to cover no. 15 & 1 & 00 & 1.13 & 31 & 5.0 & 6.13 \\
\hline 18 & spring washer z8.2 & assem with screw & 10 & 05 & 1.84 & 06 & 5.5 & 73.40 \\
\hline 19 & screw with washer & $\begin{array}{l}\text { tighten cover no. } 2 \text { to } \\
\text { main housing }\end{array}$ & 10 & 10 & 1.5 & 38 & 6.0 & 75.00 \\
\hline 20 & cover no.5 & pick up & 1 & 30 & 1.95 & & & 1.95 \\
\hline 21 & screw m8x20 & pick up & 4 & 10 & 1.5 & & & 6.00 \\
\hline 22 & spring washer z8.2 & assem with screw & 4 & 05 & 1.84 & 06 & 5.5 & 29.36 \\
\hline 23 & monolith seal & sealing & 1 & & & 99 & 12.0 & 12.00 \\
\hline 24 & screw with washer & $\begin{array}{l}\text { tighten cover } 5 \text { to main } \\
\text { housing no.1 }\end{array}$ & 4 & 10 & 1.5 & 38 & 6.0 & 30.00 \\
\hline \multicolumn{3}{|c|}{$\begin{array}{l}\text { total number of parts/operations } \\
\text { before changes }\end{array}$} & 113 & \multicolumn{4}{|c|}{$\begin{array}{l}\text { total operating time } \\
\text { before changes }\end{array}$} & 683.19 \\
\hline \multicolumn{4}{|c|}{$\begin{array}{l}\text { for serial and mass production. after the change - } 32 \text { (theoretically } 22 \text { ), } \\
\text { including unified elements - } 23 \text { (theoretically } 13 \text { ), including workpieces } \\
-9 \text {, in group machining - } 7 \text { (theoretically also } 9 \text { and } 7 \text { respectively) }\end{array}$} & \multicolumn{5}{|c|}{$\begin{array}{l}\text { for piece and small batch production, after the } \\
\text { change - } 85 \text {, including unified elements - } 71 \text {, } \\
\text { including workpieces - 14, in group machining - } 12\end{array}$} \\
\hline
\end{tabular}

results of the analysis for a cast iron gear body are better than the results of the analysis for a welded body gear. The DFMA project performance index should be as low as possible before the change it is $46 \%$ after changes depending on the production series $37 \%$ and $14 \%$ respectively.

\subsection{Lucas DFA method}

According to the Lucas DFA method, the same design of a single-stage gear prototype was analysed (Figure 1). For each assembled part and each defined step (Table 4 and 5) of the assembly process, the values of individual method indicators were determined. Results of the analysis for the assumed assembly process are presented in Tables 4 and 5. The table summarizes selected examples of operations assigning them an analysis of functionality $\left(W_{e p}\right)$ (in the form of parts belonging to group $A$ or $B)$, manouvering $\left(W_{\text {man }}\right)$, assemblability $\left(W_{m o n}\right)$ and additional operations. Data related to additional operations can be found in the Sec column [22].

The formula describing functionality $W_{e p}$ is:

$W_{e p}=L_{k A} / L_{k A}+L_{k B}=23(23+82)=0.22(22 \%)$

where: $L_{k A}$ - number of components $A$ (fulfilling the functions of a product),

$L_{k B}$ - number of components $B$ (characterised by a lack of product function e.g. rivets, washers).

Formula describing manoeuvring $W_{\operatorname{man}}$ is:

$W_{\text {man }}=I_{\text {man }} / L_{k A}=67.2 / 23=2.92$,

where: $I_{\operatorname{man}}$ - manouvering index,

$L_{k A}$ - number of components A.

Formula describing assemblability $W_{m o n}$ is:

$W_{m o n}=\left(W_{m}+W_{d}\right) / L_{k A}=284.2 / 23=12.36$, 
Table 3 Results of the technology analysis by the Boothroyd \& Dewhurst method of the gearbox - Continue

\begin{tabular}{|c|c|c|c|c|c|c|c|}
\hline \multicolumn{4}{|c|}{ details of assembly and components } & \multicolumn{4}{|c|}{ theoretical minimum number of parts/operations } \\
\hline no. & description & $\begin{array}{l}\text { initial assumption of the } \\
\text { process }\end{array}$ & $\begin{array}{l}\text { repetitions of } \\
\text { activities }\end{array}$ & $\begin{array}{l}\text { relative } \\
\text { movement }\end{array}$ & $\begin{array}{l}\text { another } \\
\text { material }\end{array}$ & $\begin{array}{l}\text { separation } \\
\text { of parts }\end{array}$ & needed? \\
\hline 1 & main housing no.1 & pick up & 1 & $\mathrm{~N}$ & $\mathrm{~N}$ & $\mathrm{Y}$ & \\
\hline 2 & bearing no. 6 & press to main housing no.1 & 1 & $\mathrm{Y}$ & $\mathrm{Y}$ & $\mathrm{Y}$ & 1 \\
\hline 3 & bearing no.13 & press to main housing no.1 & 1 & $\mathrm{Y}$ & $\mathrm{Y}$ & $\mathrm{Y}$ & 1 \\
\hline 4 & main shaft no.3 & press to bearing no. 6 & 1 & $\mathrm{Y}$ & $\mathrm{N}$ & $\mathrm{Y}$ & 1 \\
\hline 5 & $\begin{array}{l}\text { slow-speed shaft } \\
\text { no.9 }\end{array}$ & pick up & 1 & $\mathrm{Y}$ & $\mathrm{N}$ & $\mathrm{Y}$ & 1 \\
\hline 8 & spacer no. 19 & assembly on shaft subassy & 1 & $\mathrm{~N}$ & $\mathrm{~N}$ & $\mathrm{~N}$ & 0 \\
\hline 9 & preheat gear no. 9 & $\begin{array}{c}\text { preheat gear no.9 to } 180 \\
\text { deg. }\end{array}$ & 1 & $\mathrm{~N}$ & $\mathrm{~N}$ & $\mathrm{~N}$ & 0 \\
\hline 10 & shaft subassy & press to bearing no.14 & 1 & $\mathrm{Y}$ & $\mathrm{Y}$ & $\mathrm{Y}$ & 1 \\
\hline 11 & cover no. 2 & pick up & 1 & $\mathrm{~N}$ & $\mathrm{~N}$ & $\mathrm{Y}$ & 1 \\
\hline 12 & bearing no.7 & press to cover no. 16 & 1 & $\mathrm{Y}$ & $\mathrm{Y}$ & $\mathrm{Y}$ & 1 \\
\hline 13 & bearing no.14 & press to cover no. 15 & 1 & $\mathrm{Y}$ & $\mathrm{Y}$ & $\mathrm{Y}$ & 1 \\
\hline 18 & spring washer z8.2 & assem with screw & 10 & $\mathrm{~N}$ & $\mathrm{~N}$ & $\mathrm{~N}$ & 0 \\
\hline 19 & screw with washer & $\begin{array}{c}\text { tighten cover no. } 2 \text { to main } \\
\text { housing }\end{array}$ & 10 & $\mathrm{~N}$ & $\mathrm{~N}$ & $\mathrm{~N}$ & 0 \\
\hline 20 & cover no.5 & pick up & 1 & $\mathrm{~N}$ & $\mathrm{~N}$ & $\mathrm{Y}$ & 1 \\
\hline 21 & screw $\mathrm{m} 8 \mathrm{x} 20$ & pick up & 4 & $\mathrm{~N}$ & $\mathrm{~N}$ & $\mathrm{~N}$ & 0 \\
\hline 22 & spring washer z8.2 & assem with screw & 4 & $\mathrm{~N}$ & $\mathrm{~N}$ & $\mathrm{~N}$ & 0 \\
\hline 23 & monolith seal & sealing & 1 & $\mathrm{~N}$ & $\mathrm{Y}$ & $\mathrm{N}$ & 1 \\
\hline 24 & screw with washer & $\begin{array}{l}\text { tighten cover } 5 \text { to main } \\
\text { housing no. } 1\end{array}$ & 4 & $\mathrm{~N}$ & $\mathrm{~N}$ & $\mathrm{~N}$ & 0 \\
\hline & $\begin{array}{r}\text { total number } 0 \\
\text { before }\end{array}$ & $\begin{array}{l}\text { parts/operations } \\
\text { changes }\end{array}$ & 113 & theoretic & $\begin{array}{l}1 \text { minimur } \\
\mathrm{rts} / \text { operat }\end{array}$ & $\begin{array}{l}\text { number of } \\
\text { ns }\end{array}$ & 22 \\
\hline $\begin{array}{l}\text { for }: \\
\text { incl } \\
-s\end{array}$ & $\begin{array}{l}\text { rial and mass produc } \\
\text { ding unified elements } \\
\text { in group machining }\end{array}$ & $\begin{array}{l}\text { tion. after the change - } 32 \text { (th } \\
-23 \text { (theoretically } 13 \text { ), includ } \\
7 \text { (theoretically also } 9 \text { and } 7\end{array}$ & $\begin{array}{l}\text { oretically } 22 \text { ), } \\
\text { ng workpieces } \\
\text { espectively) }\end{array}$ & $\begin{array}{r}\text { for piece } \\
\text { change } \\
\text { including }\end{array}$ & $\begin{array}{l}\text { and small } \\
85 \text {, incluc } \\
\text { orkpieces }\end{array}$ & $\begin{array}{l}\text { tch producti } \\
\text { g unified ele } \\
4 \text {, in group }\end{array}$ & $\begin{array}{l}\text { fter the } \\
\text { ts - } 71 \text {, } \\
\text { ining - } 12\end{array}$ \\
\hline
\end{tabular}

where:

$W_{m}$ - main activity indicator wherein, $W_{m}=L_{m A}+L_{m B}+L_{m C}$ $+L_{m D}+L_{m E}+L_{m F}$

$W_{d}$ - indicator of additional activities, values making up the $W_{m}$ and $W_{d}$ parameters are specified in tables provided by the authors of the method,

$L_{k A}$ - number of the type A parts.

Description of calculations presented above is presented in Table 4 and 5. In the example presented, the developed structure (Figure 1) is non-technological from the point of view of the possibility of implementation into production in conditions of high-volume production. In the applied assessment method, the project efficiency index was obtained at the level of $W_{e p}=22 \%$ (authors of publications [23-24] give a minimum value of 60\%) and $W_{\text {man }}=2.92$ and $W_{\text {mon }}=12.36$ (where both indicators should be less than 2.5).

To improve the technology of the gearbox structure, the same changes were made as in the previously described method. Below are the indicators for the case of the unit and small-lot production, as well as for massproduction.
Based on the performed analysis, the number of parts of type A is $23\left(L_{k A}\right)$, the number of type B is 62 $\left(L_{k B}\right)$ for a piece and small series production.

Formulas describing functionality $W_{e p}$ after the changes are:

$W_{e p}=L_{k A} / L_{k A}+L_{k B}=23(23+62)=0.27(27 \%)$.

Based on the new data, after the changes specified in Tables 4 and 5, the manoeuvring index $I_{\text {man }}$ is:

$$
I_{\text {man }}=L_{m A}+L_{m B}+L_{m C}+L_{m D}=58
$$

where:

$L_{m A}=42$,

$L_{m B}=7.7$,

$L_{m C}=2.7$,

$L_{m D}=5.6$.

The formula for the manoeuvring factor $W_{\operatorname{man}}$ $\left(W_{d}=0\right)$ after the changes is:

$W_{\text {man }}=I_{\text {man }} / L_{k A}=58 / 23=2.52$. 
Table 4 Results of the gear assembly technology analysis

\begin{tabular}{|c|c|c|c|c|c|c|c|c|}
\hline \multicolumn{4}{|c|}{ details of assembly and components } & \multicolumn{5}{|c|}{ handling analysis } \\
\hline no. & step of assembly & description & functional analysis & A & $\mathrm{B}$ & $\mathrm{C}$ & $\mathrm{D}$ & Sum \\
\hline 1 & pick up & body no.1 & $\mathrm{A}$ & 3 & 0 & 0 & 0 & 3 \\
\hline 2 & pressing to body & bearing no.6 & A & 1 & 0.4 & 0 & 0 & 1.4 \\
\hline \multicolumn{9}{|l|}{3} \\
\hline 4 & pressing to body & bearing no.13 & A & 1 & 0.4 & 0 & 0 & 1.4 \\
\hline \multicolumn{9}{|l|}{5} \\
\hline 6 & $\begin{array}{l}\text { pressing to bearing } \\
\text { no. } 6\end{array}$ & $\begin{array}{l}\text { pinion shaft } \\
\text { no.3 }\end{array}$ & A & 1 & 0 & 0.1 & 0.2 & 1.3 \\
\hline 8 & pick up & main shaft no.9 & A & 1 & 0 & 0.1 & 0.2 & 1.3 \\
\hline 9 & assembly & wedge 11 & B & 1 & 0 & 0 & 0.2 & 1.2 \\
\hline 10 & $\begin{array}{c}\text { assembly on shaft } \\
\text { subassy }\end{array}$ & gear 7 & B & 1 & 0.4 & 0.1 & 0.2 & 1.7 \\
\hline 11 & $\begin{array}{c}\text { assembly on shaft } \\
\text { subassy }\end{array}$ & spacer sleeve 19 & B & 1 & 0 & 0 & 0 & 1 \\
\hline \multicolumn{9}{|l|}{13} \\
\hline \multicolumn{9}{|l|}{18} \\
\hline 55 & $\begin{array}{c}\text { assembly on shaft } \\
\text { subassy }\end{array}$ & $\begin{array}{l}\text { prismatic } \\
\text { wedge } 12\end{array}$ & B & 1 & 0 & 0 & 0.2 & 1.2 \\
\hline 56 & assembly to the body & vent 77 & $\mathrm{~A}$ & 1 & 0 & 0.1 & 0.2 & 1.3 \\
\hline 57 & assembly to the body & & & & & & & \\
\hline 58 & assembly to the body & oil indicator 79 & $\mathrm{~A}$ & 1 & 0 & 0.1 & 0.2 & 1.3 \\
\hline \multicolumn{9}{|l|}{59} \\
\hline 60 & assembly to the body & plug 81 & $\mathrm{~A}$ & 1 & 0 & 0.1 & 0.2 & 1.3 \\
\hline 61 & assembly to the body & sealing ring 82 & $\mathrm{~A}$ & 1 & 0 & 0.1 & 0.2 & 1.3 \\
\hline 63 & pick up and setup & nameplate & B & 1 & 0.2 & 0.1 & 0.2 & 1.5 \\
\hline 64 & riveting & rivet & B & 1.5 & 0.2 & 0 & 0 & 1.7 \\
\hline \multicolumn{9}{|l|}{65} \\
\hline \multicolumn{9}{|l|}{66} \\
\hline \multicolumn{9}{|l|}{82} \\
\hline 83 & & & & 48 & 11 & 2.7 & 5.6 & 67.2 \\
\hline \multicolumn{9}{|l|}{84} \\
\hline & & $22 \%$ & & 2.92 & & & & \\
\hline & proje & t efficiency ratio & & & & erabi & & \\
\hline
\end{tabular}

The formula for the main activity ratio $W_{m}$ after the changes are:

$W_{m}=L_{p A}+L_{p B}+L_{p C}+L_{p D}+L_{p E}+L_{p F}+S e c=246.7$

where: $L_{p A}=104$,

$L_{p B}=1.9$,

$L_{p C}=7.7$,

$L_{p D}=15$,

$L_{p E}=12$,

$L_{p F}=7$,

$\mathrm{Sec}=99$

The formula for assemblability factor $\mathrm{W}_{\text {mon }}$ after the changes is:

$W_{m o n}=W_{m} / L_{k A}=246.7 / 23=10.73$
Based on the performed analysis, the number of parts of type A is $18\left(L_{k A}\right)$, the number of type B is 14 $\left(L_{k B}\right)$ for serial and mass production.

Formula, describing functionality $W_{e p}$ after the changes, is:

$W_{e p}=L_{k A} / L_{k A}+L_{k B}=18(18+14)=0.56(56 \%)$.

Based on the new data after the changes specified in Tables 4 and 5, the manoeuvring index $I_{\operatorname{man}}$ is:

$I_{\text {man }}=L_{m A}+L_{m B}+L_{m C}+L_{m D}=35.2$,

where: $L_{m A}=27$,

$L_{m B}=4.3$,

$L_{m C}=1.4$,

$L_{m D}=3$. 
Table 5 Results of the gear assembly technology analysis - Continued

\begin{tabular}{|c|c|c|c|c|c|c|c|c|c|c|}
\hline \multirow[t]{2}{*}{ no. } & & \multicolumn{9}{|c|}{ fitting analysis } \\
\hline & & $\mathrm{A}$ & $\mathrm{B}$ & $\mathrm{C}$ & $\mathrm{D}$ & $\mathrm{E}$ & $\mathrm{F}$ & sec. & sum & cumulative sum \\
\hline 1 & pick up and place & 1 & 0 & 0 & 0 & 0 & 0 & 0 & 1 & 1 \\
\hline 2 & pressing & 1 & 0 & 0 & 0 & 0 & 0.7 & 0 & 1.7 & 2.7 \\
\hline 3 & baring position measure & 1.3 & 0.1 & 0 & 1.5 & 0 & 0 & 1.5 & 4.4 & 7.1 \\
\hline 4 & pressing & 1 & 0 & 0 & 0 & 0 & 0.7 & 0 & 1.7 & 8.8 \\
\hline 5 & baring position measure & 1.3 & 0.1 & 0 & 1.5 & 0 & 0 & 1.5 & 4.4 & 13.2 \\
\hline 6 & pick up and hold down & 1 & 0 & 0 & 0 & 0 & 0 & 0 & 1 & 14.2 \\
\hline 8 & pick up and place & 1 & 0 & 0 & 0 & 0 & 0 & 0 & 1 & 18.6 \\
\hline 9 & assembly on shaft subassy & 1 & 0 & 0 & 0 & 0.7 & 0 & 0 & 1.7 & 20.3 \\
\hline 10 & assembly on shaft subassy & 2 & 0.1 & 0 & 0 & 0.7 & 0.7 & 0 & 3.5 & 23.8 \\
\hline 11 & assembly on shaft subassy & 1 & 0.1 & 0 & 0 & 0 & 0 & 0 & 1.1 & 24.9 \\
\hline \multicolumn{11}{|l|}{13} \\
\hline \multicolumn{11}{|l|}{18} \\
\hline 55 & assembly on shaft subassy & & & & & & & & & \\
\hline 56 & pick up and place & 1 & 0 & 0 & 0 & 0.7 & 0 & 0 & 1.7 & 243.3 \\
\hline 57 & tightening & 1 & 0 & 0 & 0 & 0 & 0 & 0 & 1 & 244.3 \\
\hline 58 & pick up and place & 4 & 0.1 & 0 & 0 & 0 & 0 & 0 & 4.1 & 248.4 \\
\hline 59 & tightening & 1 & 0 & 0 & 0 & 0 & 0 & 0 & 1 & 249.4 \\
\hline 60 & pick up and place & 4 & 0.1 & 0 & 0 & 0 & 0 & 0 & 4.1 & 253.5 \\
\hline 61 & assembly on plug & 1 & 0 & 0 & 0 & 0 & 0 & 0 & 1 & 254.5 \\
\hline 63 & pick up and place & 1 & 0.1 & 0 & 0 & 0 & 0 & 0 & 1.1 & 255.6 \\
\hline 64 & pick up and place & 2 & 0.1 & 0 & 0 & 0.7 & 0 & 0 & 2.8 & 262.5 \\
\hline 65 & riveting & 2 & 0.1 & 0 & 0 & 0 & 0 & 0 & 2.1 & 264.6 \\
\hline 66 & additional rivets & 4 & 0.1 & 0 & 0 & 0.7 & 0 & 0 & 4.8 & 269.4 \\
\hline 82 & & 2 & 0.1 & 0 & 0 & 0.7 & 0 & 12 & 14.8 & 284.2 \\
\hline 83 & & & & & & & & & & 284.2 \\
\hline \multirow[t]{4}{*}{84} & & & & & & & & & & 284.2 \\
\hline & & 108 & 2.1 & 11 & 18 & 12 & 7 & 127 & & 284.2 \\
\hline & & & & & & & & & & 284.2 \\
\hline & manouverity index & \multicolumn{8}{|c|}{ mounting index } & 12.36 \\
\hline
\end{tabular}

The formula for the manoeuvring factor $W_{\text {man }}$ after $\quad\left(W_{d}=0\right)$ after the changes is: the changes is:

$W_{\text {man }}=I_{\text {man }} / L_{k A}=35.2 / 18=1.96$.

The formula for the main activity ratio $W_{m}$ after the changes is:

$W_{m}=L_{p A}+L_{p B}+L_{p C}+L_{p D}+L_{p E}+L_{p F}+S e c=112.8$

where:

$L_{p A}=54$,

$L_{p B}=1.4$,

$L_{p C}=0$,

$L_{p D}=7.5$,

$L_{p E}=9.1$,

$L_{p F}=6.3$,

$\mathrm{Sec}=35$.

The formula for the assemblability factor $W_{m o n} \quad W_{u n k}=91 / 91+105=0.46(46 \%)$.
$W_{\text {mon }}=W_{m} / L_{k A}=112.8 / 18=6.27$.

According to calculations presented above, it can be stated that the analysis results for a cast iron gear body are better than the analysis results for a welded body gear. The $W_{\text {mon }}$ project performance indicator should be as high as possible, before the change $22 \%$, after the change of $27 \%$ and $56 \%$, respectively, according to the series production. The maneuvering and assemblability factors of $W_{\operatorname{man}}$ and $W_{\text {mon }}$ should be as low as possible; before the change they are respectively 2.92 and 12.35 , after the change they depend on the production series $W_{\text {man }}=2.52$ and 1.96 and $W_{\text {mon }}=10.73$ and 6.27.

The unification and batch processing ratios, for both methods before the redesigning, are as follows: 
After the redesign for the small lot production:

$W_{u n k}=71 / 71+85=0.45(45 \%)$.

After the redesign for the mass production:

$W_{\text {unk }}=23 / 23+32=0.42(42 \%)$.

In the case of the gearboxes from the unification index (machining) before redesigning is:

$W_{\text {uno }}=5 / 5+14=0.26(26 \%)$.

After the redesign for the small lot production

$W_{\text {uno }}=12 / 12+14=0.46(46 \%)$

After the redesign for the mass production: (including theoretically):

$W_{\text {uno }}=7 / 2+7=078(78 \%)$.

The presented results meet the assessment of the used production methods effectiveness in the production practice.

\section{Conclusions and comments}

The standard analysis of B\&D and Lucas DFA is associated with a reduction in the number of parts that do not have a significant impact on the product's functions or their change consisting in improvement in terms of the assembly method. This change may be associated with an increase in manufacturing costs. In modified methods by introducing indicators unification and possibilities of group processing, it is possible to improve the design more accurately. Original methods are oriented towards the mass production. Modified methods improve original ones giving the possibility of use in production with smaller series, as well. Analysis of unification and group machining indicators allow for the unification of components and thus saving investment in machines and shorter overall assembly time. Their use can contribute to design of products with higher efficiency and lower production costs.

Proposals for modification of methods allow the analysis of the obtained values of the assembly efficiency assessment parameters, which also causes:

- shortening of times, elimination of errors, reduction of process costs,

- considering, in addition to assembly many other various factors, e.g. availability of spare parts, production seriality, production conditions in the form of equipment types, available assembly techniques, level of automation, the scope of external cooperation orders, etc.

- the use of methods for smaller series of manufactured products,

- $\quad$ stimulating a designer's creativity.

These two methods cannot be compared directly due to the different way of calculations. The following conclusions can be drawn from analysis of comparison of results obtained by both methods.

The Boothroyd-Dewhurst method is more stringent and is aimed at reducing/simplifying the components of the project. At the same time, in the case of production not qualified for the high-volume production, the result of such an assessment may be a product with a small number of components, but a very complicated form and, therefore, a high cost of processing and quality and other in the field of production organisation.

The Lucas method assesses the above project in a more balanced way. It enables the assessment of technology from the point of view of value of several parameters. Differences in relation to the intended goal between the two methods are not large. Both methods, together with complex proposals, allow universalisation of the presented methods and their application to conditions of the unit and small-lot production.

\section{References}

[1] ABDULLAH, A., POPPLEWELL, K., PAGE, C. J. A review of the support to tools for the process of assembly method selection and assembly planning. International Journal of Production Research [online]. 2003, 41(11), p. 2391-2410 [accessed 2020-01-27]. ISSN 1366-588X. Available from: https://doi.org/10.1080/002075431000087265

[2] BOOTHROYD, G., DEWHURST, P. Design for assembly. A designer's handbook. Amherst, Ma.: University of Massachusetts, Department of Mechanical Engineering, 1983.

[3] KNIGHT, W. A., BOOTHROYD, G. Fundamentals of metal machining and machine tools. 3. ed. Taylor and Francis Group: CRC Press, 2005. ISBN 978-157-444-659-3.

[4] BREYFOGLE, F. W. Implementing six sigma. 2. ed. New Jersey: John Wiley and Sons, 2003. ISBN 978-0471265726.

[5] EGAN, M. Design for assembly in the product development process-a design theory perspective. Thesis for the degree of licentiate of Engineering. Marina del Rey, 1997. ISBN 99-248946-85.

[6] DOCHIBHATLA, S. V. S., BHATTACHARYA, M., MORKOS, B. Evaluating assembly design efficiency: a comparison between Lucas and Boothroyd-Dewhurst methods. In: International Design Engineering Technical 
Conferences and Computers and Information in Engineering Conference ASME 2017: proceedings. 2017. p. V004T05A012-V004T05A012.

[7] AHMAD, M. N., ADEERA, N., OSMAN MAZRAN, M. H., KHALID, M. The significant improvement on the design of pedestrian traffic light using Boothroyd Dewhurst design for assembly (DFA) method: a case study. Journal of Advanced Research Design. 2016, 25(1), p. 11-19. eISSN 2462-1943.

[8] CHANG, T. C. Expert process planning for manufacturing. NY: Addison-Wesley Publishing Company, Inc., 1990. ISBN-13: 978-0201182972.

[9] MATUSZEK, J. Production engineering /Inzynieria produkcji (in Polish). Bielsko-Biala: Wydawnictwo Politechniki Lodzkiej Filii, 2000. ISBN 83-87087-97-1, p. 83-109.

[10] LIBERS, A., SREPPEL, A., SCHUTTERT, M., KALS, H. Part classification for variant cost estimation. In: 4th International Conference on Sheet Metal: proceedings. Vol. 2. SheMet, 1996. ISBN 903-650-804-5, p. 167-178.

[11] OHASHI, T., MIYAKAWA, S. The Hitachi assemblability evaluation method (AEM). In: 1st International Conference on Product Design for Assembly: proceedings. 1986.

[12] GREGOR, M., MATUSZEK, J. Production systems development trends / Tendencje projektowania systemow produkcyjnych (in Polish). Mechanik [online]. 2013, 7, p. 231-238 [accessed 2020-01-27]. ISSN 0025-6552. Available from: http://www.mechanik.media.pl/pliki/do_pobrania/artykuly/2/4924_231_238.pdf

[13] MATUSZEK, J., SENETA, T. Algorithmisation of the new product implementation process in the conditions of mass production / Algorytmizacja procesu wdrazania nowegp produktu w warunkach wielkoseryjnej produkcji (in Polish). Mechanik [online]. 2016, 7, p. 755-757 [accessed 2020-01-27]. ISSN 0025-6552. Available from: http:// www.mechanik.media.pl/pliki/do_pobrania/artykuly/22/konferencja_158.pdf

[14] HERBERTSSON, J. Enterprise oriented design for manufacture - on the adaptation of DFM in an enterprise. Ph.D. thesis. LiTH, 1999.

[15] JAMES, A., GANDHI, O. P., DESHMUKH, S. G. Development of methodology for the disassemblability index of automobile system using a structural approach. Proceedings of the Institution of Mechanical Engineers, Part D: Journal of Automobile Engineering [online]. 2016, 231(4), p. 516-535 [accessed 2020-01-27]. ISNN 0954-4070. Available from: https://doi.org/10.1177/0954407016656311

[16] PAN, L., CHO, H. J., PARK, J. I. Study on the design factors affecting the operating actions that can be used easily at the design stage. Advanced Materials Research [online]. 2015, 1061-1062, p. 712-715 [accessed 2020-0127]. ISSN 1662-8985. Available from: https://doi.org/10.4028/www.scientific.net/AMR.1061-1062.712

[17] MATUSZEK, J., SENETA, T. Evaluation of design manufacturability in new product production launches by Lucas DFA method. Mechanik [online]. 2017, 7, p. 755-757 [accessed 2020-01-27]. Available from: http://www.mechanik. media.pl/pliki/do_pobrania/artykuly/22/2017_07_s0523_eng.pdf

[18] MATUSZEK, J., KOLOSOWSKI, M., KROKOSZ-KRYNKE, Z. Cost accounting for engineers / Rachunek kosztow dla inzynierow (in Polish). Warszawa: Polskie Wydawnictwo ekonomiczne, 2014. ISBN 978-83-208-2104-8, p. 215247.

[19] SHETTY, D., ALI, A. A new design tool for DFA/DFD based on rating factors. Assembly Automation [online]. 2015, 35(4), p. 348-357 [accessed 2020-01-27]. ISSN 0144-5154. Available from: https://doi.org/10.1108/AA-112014-088

[20] SHUKOR, A. I. A., ADAM, A. Evaluation of design efficiency using Boothroyd Dewhurst method for PCB drilling machine product. International Journal of Simulation Systems, Science and Technology [online]. 2018, 19(5), p. 4.1-4.8 [accessed 2020-01-27]. ISSN 1473-8031, ISSN 1473-804x. Available from: https://doi.org/10.5013/ IJSSST.a.19.05.04

[21] SWIFT, K. G., BOOKER, J. D. Process selection from design to manufacture. 2. ed. Oxford: Elsevier, 2003. ISBN 0750654376.

[22] SWIFT, K., BROWN, N. Design for assembly / manufacturing analysis practitioner's manual. Version 10.5. Great Britain: University of Hull, 1994. ISBN 978-0-13-516569-0, p. 116-138.

[23] WIECEK, D., WIECEK, D. (2017). The influence of the methods of determining cost drivers values on the accuracy of costs estimation of the designed machine elements. In: International Conference on Information Systems Architecture and Technology: proceedings. Cham: Springer. 2017. p. 78-88.

[24] WIECEK, D., WIECEK, D., KURIC, I.: Cost estimation methods of machine elements at the design stage in unit and small lot production conditions. Management Systems in Production Engineering [online]. 2019, 27(1), p. 12-17. eISSN 2450-5781. Available from: https://doi.org/10.1515/mspe-2019-0002 